\title{
Toward a framework for strengthening participants' self-efficacy in online education
}

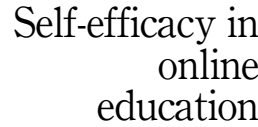

\author{
Department of Education, Bankura University, Bankura, India
}

Arnab Kundu

\begin{abstract}
Purpose - The purpose of this study was to review the role of self-efficacy in online education with an objective to propose a holistic framework for strengthening participants' self-efficacy, especially in the Asian context.

Design/methodology/approach - To investigate the potential role of self-efficacy of the participants of online academic activities, this study followed the conceptual analysis method, which is breaking down concepts into constituent elements to get a superior understanding of a particular philosophy.

Findings - The findings revealed that self-efficacy, the level of confidence someone has to perform a particular task, is an important factor among teachers and students operating online platforms, and enhanced efficacy is capable of encouraging online practices. Finally, the study proposed a framework to strengthen self-efficacy among participants with intervention measures to make online education effective and impressive.

Research limitations/implications - The proposed framework will help stakeholders of online education to improve their efficacy and leverage the potential of online education to the fullest. Millions of first-generation online users in many Asian countries who possess low self-confidence in their ability might find the framework easier for better integration, interaction and collaboration in the online learning environment.

Originality/value - A vast literature survey was made before proposing this framework that could open up a new dimension in online education by scaffolding participants' inner thrust.
\end{abstract}

Keywords Self-efficacy, Online education, Framework for online education, Asian practitioners

Paper type Research paper

\section{Introduction}

Mahatma Gandhi, the great Asian thinker, said a person often becomes what he believes himself to be, meaning if he keeps on believing that he cannot do a certain thing, he will never succeed; reversely if he keeps on believing that he can do it, he will surely acquire the capacity to do it even if he may not have it at the beginning (Deats, 2005). This "self-belief" which was later extensively researched as "self-efficacy" by Albert Bandura in his "social cognitive theory" refers to beliefs in one's capabilities to organize and implement the courses of action needed to produce given accomplishment and having exclusive power to predict one's behavior (Bandura, 1997, p. 3). Self-efficacy determines and controls people's thoughts and the ways they act or behave (Alqurashi, 2016). Peterson and Arnn (2005) said self-efficacy is the basis of human performance, and it is significant to examine the factors that affect selfefficacy along with the desired behaviors. Self-efficacy beliefs find answer for the question: Can I do this? Hodges (2008) further finds this is situation specific, and individuals may find self-efficacy belief varying from situation to situation.

In an educational setting, understanding self-efficacy with respect to various academic practices is significant because it has a deep impact on the aims, effort and achievement of the

(C) Arnab Kundu. Published by Emerald Publishing Limited. This article is published under the Creative Commons Attribution (CC BY 4.0) licence. Anyone may reproduce, distribute, translate and create derivative works of this article (for both commercial and non-commercial purposes), subject to full attribution to the original publication and authors. The full terms of this licence may be seen at http:// creativecommons.org/licences/by/4.0/legalcode

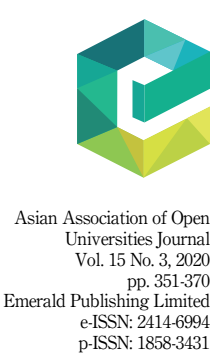

DOI 10.1108/AAOUJ : $1858-343$
Received 18 July 2020 Revised 14 September 2020 15 September 2020 17 September 2020 18 September 2020 Accepted 18 September 2020 
AAOUJ 15,3

352 participants. A lot of past studies have examined the importance of participants' self-efficacy with respect to their use of online education strongly suggests a link between self-efficacy and technology use potential (Sun and Chen, 2016; Corry and Stella, 2018). Honicke and Broadbent (2016) said using an online platform for education makes sense because today's students are digital natives, and the majority of these students are well adept at using technology that a learner's academic self-efficacy is bravely associated with academic performance. Different from conventional face-to-face classroom lecturing, technologyenhanced learning not only facilitates the showcasing of multimedia teaching materials but also encourages students to take initiatives to research on their own and to share with peers about their personal insights into online forums (Tsai, 2017). Thus, the construct of selfefficacy sounds like a recipe for academic success so far as online education is concerned. Hence, in this literature review the role of self-efficacy in online education, especially in the Asian context, was studied. In total, three main areas of research were identified for this review: (1) role of self-efficacy in online education, especially in the Asian context, (2) factors influencing self-efficacy in online education and (3) a framework for strengthening participants' self-efficacy in online education.

\section{Self-efficacy}

Bandura (1997) found self-efficacy to be important because people with high self-efficacy are more likely to make an effort to change their work environment and persist at their work when facing negative outcome expectations. Conversely, people with low self-efficacy are more likely to have feelings of hopelessness and despondency and less likely to persist in similar situations. The stronger their notion of self-efficacy, the better their effort, perseverance, resilience and elasticity (Bandura, 2001), meaning a strong notion of selfefficacy creates feelings of tranquility and provides power to challenge at the face of difficult tasks. It, in all forms, influences our thoughts, emotions, actions, motivation and operates mainly through the cognitive and affective channels and plays a crucial role in shaping our perception of life experiences (Chowdhury, 2020). The summed up effects of having strong self-efficacy can be framed in the following manner, as presented in Figure 1 below.

The perceived self-efficacy determines not only the level of effort but also its quality, i.e. how productively that effort is deployed. Therefore, higher perceived self-efficacy brings about various motivated efforts, and it enables individuals to enhance performances (Talsma et al., 2018). In this context, Bandura (2001) said self-efficacy theory is a common theme in relation to motivation, mostly as a result of its power to predict one's behavior. He suggested that the interplay of environmental factors with people having low or high self-efficacy predicts four variables: success, depression, apathy, effort maximizing (Bandura, 1997). They can be interpreted with the help of the following diagram (see Figure 2).

Bandura's (1997) introduction of self-efficacy theory contained the proposition that self-efficacy perceptions depends on environmental, cognitive and behavioral effects that a person experiences in his/her everyday life. Based on this observation, he said that selfefficacy is derived from four major sources: performance accomplishments, verbal persuasion, vicarious experience and physiological-affective states (see Figure 3). These four areas are accepted as the core elements in the development of self-efficacy and by the interplay of these factors that grow significant belief or disbelief in human in general.

\section{Self-efficacy in the academic context}

Bandura's social-cognitive theory (2001) recognizes that human learning is based upon a system of three forces: social, personal and behavioral, each of which influences one another 

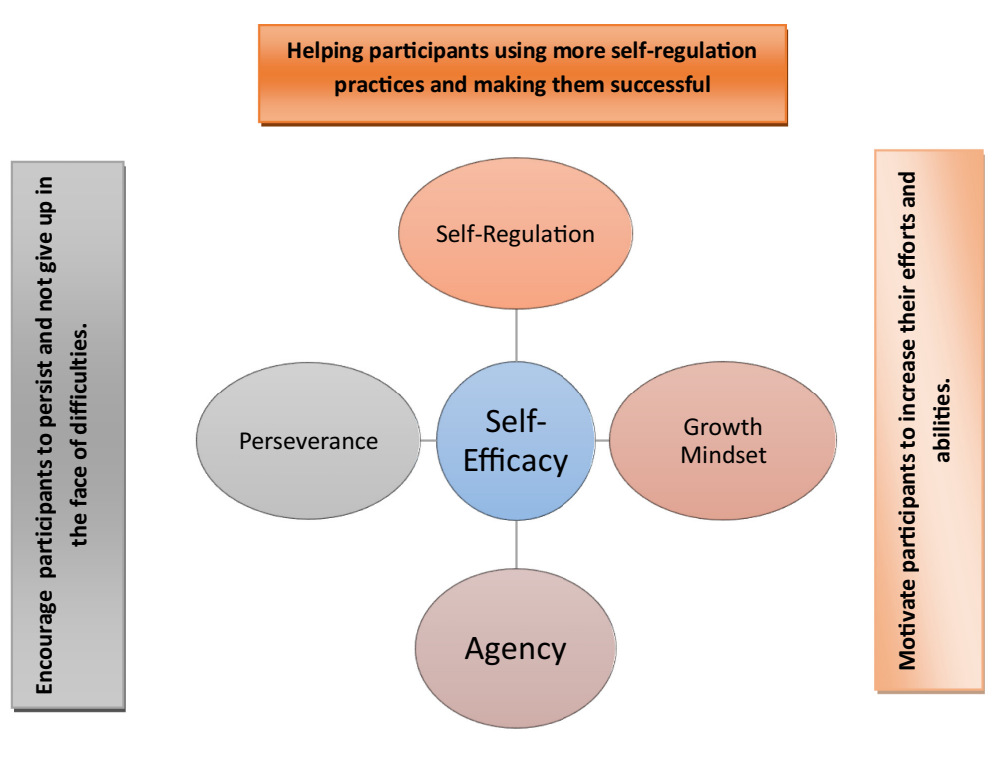

Self-efficacy in online
education

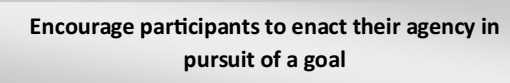

Figure 1. Effects of having high self-efficacy

EN VIRONMENT

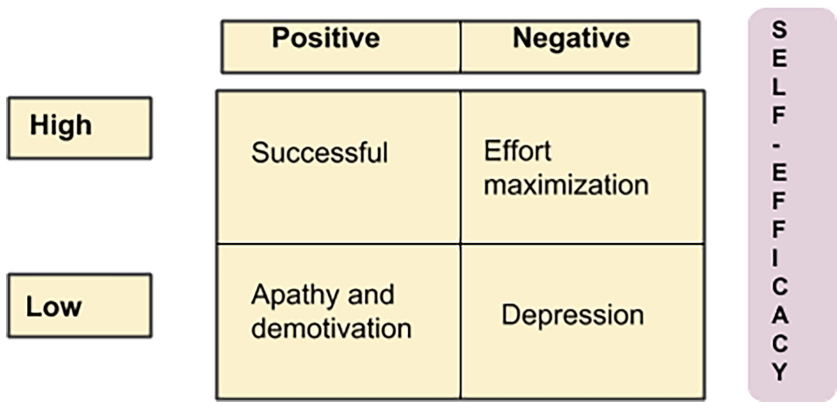

Figure 2. Self-efficacy and environment interplay

to affect human development as what Woolfolk (2011) said triarchic reciprocal causality process. Self-efficacy beliefs, by extension, academic self-efficacy, fall within the personal domain of this process. Honicke and Broadbent (2016) said self-efficacy beliefs influence academic performance of both teachers and students. Students with high self-efficacy have better self-regulation and are more resilient in facing obstacles (Bandura, 2001), demonstrate stronger academic performance and achievement, have increased confidence in their self-regulated learning which affects their engagement and academic achievements thus increases their grades and, eventually, are happier all around (LaRocca, 2017). On the other hand, teachers' with high self-efficacy are more capable in orchestrating 


\section{AAOUJ 15,3}

\section{4}

Figure 3.

Principle sources of self-efficacy (cited in Bandura, 1997)

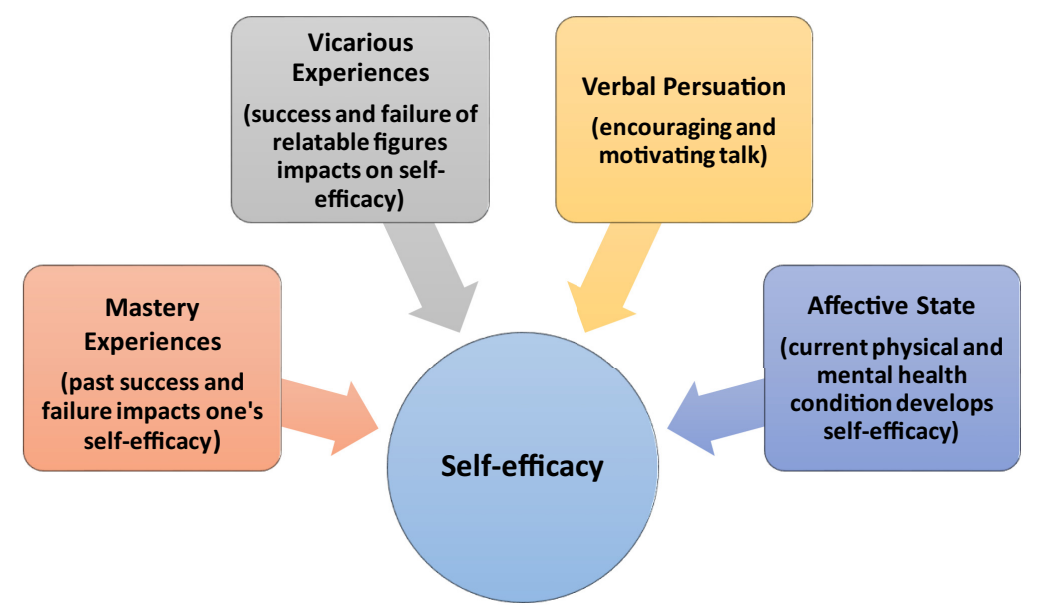

teaching-learning activities to bring about "desired changes on student engagement and learning" (Tschannen-Mora et al., 1998, p. 783). This makes the teacher "capable of carrying out good teaching" (Christophersen et al., 2016, p. 241), provides job satisfaction and professional commitment (Joo et al., 2013), diminishes attrition (Pellas, 2014) and even influences his/her attitudes for successful integration of technology (Hatlevik and Hatlevik, 2018).

\section{Purpose of the study}

Thus, self-efficacy, the intrinsic self-belief, has a big role in academic activities, including online education (Pumptow and Brahm, 2020). Bandura (1997) himself found that because of the swift progress of technological tools, the pedagogical use of technology may require special and ever-evolving types of teacher self-efficacy.

Since the focus of this study was Asia, it needs a brief analysis of online education scenario in Asian countries here. Asia consists of 49 countries, 36 of which had been specifically classified as developing countries based on World Bank Country Classifications (The World Bank, 2019). During the last ten years, enrollment in education (school level to higher education) in Asia has been observed to increase by over 55\% (Paul Glewwe, 2020). This growth in the population and the demand for education are coupled with the projection that "the 21st century will be the Asian Century which is overdue and inevitable" (Bandalaria, 2018, p. 116). This huge learner explosion is beyond capacity of traditional system to cater their academic needs; hence, online education has been gaining traction. There is a huge developing potentiality of online education in Asian countries during coming decades although it has several big challenges to face like uneven development, high cost of establishing a system, uneven teaching quality, cultural bigotry and unfair practice (Kundu and Bej, 2020).

The gap regarding online education between Western and Asian countries is obvious; in this context, Ahmed et al. (2017, p. 102) found "Western online education platforms are undoubtedly valuable but they lack our domestic cultural needs and practices." This cultural difference can be convincingly illustrated by the four-dimensional model of cultural differences (see Table 1) developed by Hofstede (1986).

Numerous studies that have examined the cultural differences between Western and Eastern educations have provided a consistent picture that describes Eastern education as 
group-based and teacher-dominated where the students are not encouraged to question or challenge a teacher's knowledge, centrally organized pedagogical culture with examinations as the essential way to define performance. In Western education, to challenge a teacher or tutor is seen as part of the self-development process as dialogue and interaction are encouraged in the learning process that is more commensurate to the online education (Liu et al., 2010). Besides these cultural barriers, digital inclusion in most of the Asian countries to facilitate online learning is uneven which cannot be rooted out overnight. Accepting these limitations, the current study researched how participants' self-efficacy could help them to continue online education amidst these challenges and how their efficacy level could be strengthened. The specific research questions set for this study were as follows:

(1) What is the role of self-efficacy in online education, especially in the Asian context?

(2) What are the factors influencing self-efficacy in online education?

(3) How to strengthen participants' self-efficacy in online education?

\section{Method}

This study followed the method of conceptual analysis to study the potential role of the participants' self-efficacy in online education. Conceptual analysis consists primarily in breaking down or analyzing concepts into their constituent parts, in order to gain knowledge or a better understanding of a particular philosophical issue in which the concept is involved (Beaney, 2003). The method of conceptual analysis wants to approach such a problem by breaking down the principle concepts relating to the problem and observing how they interact.

\section{Data collection}

The author used secondary data source for analysis that include past research articles and organizational records (mainly of empirical nature). The articles used for literature survey were selected from the education-specific databases of JSTOR digital library, Web of Science, Eric and SCOPUS. A search criterion was developed to select articles for online education to overcome the nonstandardized nomenclature, as stated by Corry and Stella (2012). The first selection criterion was "online education" or "online learning" published within the last 20 years. The second criteria were "general self-efficacy", "Internet self-efficacy", "computer self-efficacy" and "online self-efficacy". The third criteria were "factors influencing online self-efficacy", "Internet self-efficacy" and "computer self-efficacy”. General search produced

\begin{tabular}{ll}
\hline Dimensions & Descriptions \\
\hline Power distance (PD) & $\begin{array}{l}\text { The degree to which people accept the unequal distribution of power and wealth in } \\
\text { a society. High PD is quite evident in Asian countries, especially in India } \\
\text { The tendency of members of a society to act as individuals or members of a larger } \\
\text { Individualism- } \\
\text { collectivism }\end{array}$ \\
$\begin{array}{l}\text { Gncertainty avoidance } \\
\text { individuality in Asian countries } \\
\text { The degree of threat an individual feels while facing an uncertain or unknown } \\
\text { The }\end{array}$ & $\begin{array}{l}\text { situation and unstructured ideas. This high UA is the hallmark of Asian societies, } \\
\text { especially in India, and people fears to adapt an exceptional path } \\
\text { The degree to which the society prefers distinct gender roles. In Asian countries, } \\
\text { gender difference is obvious, and women empowerment is not under process and } \\
\text { far below the expected state of equity }\end{array}$
\end{tabular}

Table 1.

Illustration of Hofstede's fourdimension culture model in the Asian context 
AAOUJ 15,3

\section{6}

1886 articles relating self-efficacy in online academic scenario, which were then limited to 50 empirical articles on the basis of particular search of factors influencing participants' selfefficacy for online education. This is especially true for the Asian context that we have searched for developing a framework, the main focus of this study. Then the abstracts of the selected 50 articles (40 made in Asian context) were closely read. The search strategy is presented in Figure 4.

\section{Data analysis}

Document analysis was used to classify the research studies by research area/theme. Document analysis is a social research method and is an important research tool in its own right to give voice and meaning around an assessment topic and is an invaluable part of most schemes of triangulation, the combination of methodologies in the study of the same phenomenon (Bowen, 2009). It involves skimming (superficial examination), reading (thorough examination) and interpretation. Here the researcher as an analyst should determine the relevance of documents to the research problem and purpose. Also, the researcher should ascertain whether the content of the documents fits the conceptual framework of the study. It is necessary, as well, to determine the authenticity, credibility, accuracy and representativeness of the selected documents. This study followed the overall recipe of O'Leary (2014) who outlines an eight-step planning process that should take place in document analysis with few changes.

\section{Results}

Details of the document analysis of 50 studies are presented in this section in Table 2 along with their respective outcomes in the context of this study.

\section{Discussion}

$R Q 1$. Role of self-efficacy in online education, especially in the Asian context

With regard to the effect of self-efficacy on academic performance in online learning environment, most of the above studies (in Table 2) found that it has a positive correlation with academic performance. In this context, the remark of Hodges (2008) becomes pertinent that the role of self-efficacy in online environments is only in its infancy that needs more studies. To this note, subsequent researchers studied the role of self-efficacy in online education, and the spotlight of these studies mostly was on the technology factor of self-

Figure 4.

Example of a fullsearch strategy
Databases: Scopus (556 articles), JSTOR digital library(339), Web of Science (329

articles), and ERIC (662 articles) = Total: 1886 articles

\begin{tabular}{lll}
\hline Search terms (Stage 1) & Search terms ( Stage 2) & Search terms ( Stage 3) \\
- 'online education' & - 'general self-efficacy' & ' \\
- 'online learning' & - 'internet self-efficacy' & self-efficacy, internet self- \\
& - 'computer self-efficacy' & efficacy, and computer self- \\
& online self-efficacy' & efficacy' \\
$\mathbf{5 0}$ articles selected & &
\end{tabular}




\begin{tabular}{|c|c|c|}
\hline No & Author(s) & Study \\
\hline 1 & $\begin{array}{l}\text { Lynch and } \\
\text { Dembo (2004) }\end{array}$ & $\begin{array}{l}\text { The Relationship Between Self- } \\
\text { Regulation and Online Learning in a } \\
\text { Blended Learning Context }\end{array}$ \\
\hline 2 & $\begin{array}{l}\text { Jashapara and } \\
\text { Tai (2006) }\end{array}$ & $\begin{array}{l}\text { Understanding the complexity of } \\
\text { human characteristics on e-learning } \\
\text { system: an integrated study of dynamic } \\
\text { individual differences on user } \\
\text { perceptions of ease of use }\end{array}$ \\
\hline 3 & $\begin{array}{l}\text { Bates and } \\
\text { Khasawneh } \\
(2007)\end{array}$ & $\begin{array}{l}\text { Self-efficacy and college student' } \\
\text { perceptions and use of online learning } \\
\text { systems }\end{array}$ \\
\hline 4 & $\begin{array}{l}\text { Kitsantas and } \\
\text { Chow (2007) }\end{array}$ & $\begin{array}{l}\text { College students' perceived threat and } \\
\text { preference for seeking help in } \\
\text { traditional, distributed and distance } \\
\text { learning environments }\end{array}$ \\
\hline 5 & $\begin{array}{l}\text { Lee and Hwang } \\
(2007)\end{array}$ & $\begin{array}{l}\text { The effects of computer self-efficacy } \\
\text { and learning management system } \\
\text { quality on e-Learner's satisfaction }\end{array}$ \\
\hline 6 & $\begin{array}{l}\text { Yukselturk and } \\
\text { Bulut (2007) }\end{array}$ & $\begin{array}{l}\text { Predictors for student success in an } \\
\text { online course }\end{array}$ \\
\hline
\end{tabular}

7 Lin et al. (2008) Building a social and motivational framework for understanding satisfaction in online learning

$8 \quad$ Wang and $\mathrm{Wu}$ (2008)

$9 \quad$ Hodges (2008)

10 Chu (2010)

11 Chu and $\mathrm{Chu}$ (2010)

12 Shea and Bidjerano (2010)

13 Law et al. (2010)

14 Martin et al. (2010)
Outcome

Learners' self-efficacy related

significantly to their academic performance in blended environment E-learning system self-efficacy, computer anxiety, personal innovativeness with IT, computer playfulness and computer experience influence perceived ease of use

Self-efficacy in online education

Relationships between self-efficacy, its antecedents, and several online learning outcomes are significant and complex Student achievement is significantly correlated with formal help seeking, academic self-efficacy and perceived threat to seek help

Learners' satisfaction and self-regulated learning strategy depends on their computer self-efficacy

The effect of the self-regulation variables on students' success was statistically significant and successful students generally used self-regulated learning strategies in the online course

The students' perceived task value, self efficacy and social ability are very important for satisfaction in online learning

Self-efficacy predicted students' use of learning strategies and related to elaborated feedback behavior SELMA among 196 participants was measured and statistically significant relationships were found between SELMA and learners' achievement Emotional family support plays a main role in predicting the effects of e-learning, mediated by general and Internet selfefficacy

Internet self-efficacy (ISE) was found having the mediation effects of between peer support and e-learning outcomes

A positive relationship exists between learner self-efficacy measures and their ratings of the quality of learning in virtual environments

A well facilitated e-learning setting can enhance learning motivation and selfefficacy

Found a significant positive correlation of self-efficacy with course performance for the students in the hybrid online course
Table 2.

Summary of research on self-efficacy in online education 


\section{AAOUJ 15,3}

\section{Zhang et al. (2012)}

18 So et al. (2012)

19 Shen et al. (2013)

20 Lin et al. (2013)

21 Putwain et al. (2013)

22 Wang et al. (2013)

23 Joo et al. (2013)

24 Cho and Shen (2013)

25 Chiu and Tsai (2014)

26 Pellas, N. (2014)
Academic self-efficacy in study-related skills and behaviors: Relations with learning-related emotions and academic success

Student' characteristics, self-regulated learning, technology self-efficacy, and course outcomes in online learning

Locus of control, self-efficacy, and task value as predictors of learning outcome in an online university context Self-regulation in online learning

The roles of social factor and Internet self-efficacy in nurses' web-based continuing learning

The influence of computer self-efficacy, meta-cognitive self-regulation and selfesteem on student engagement in online learning programs: Evidence from the virtual world of Second Life

\section{Outcome}

Prior knowledge of online system showed a positive direct effect on online selfefficacy

Personal innovativeness with IT showed significant an effect on e-learning system self-efficacy, and computer experience had a significant effect on e-learning system self-efficacy

Found positive influence of the psychological safety communication climate on self-efficacy

Found student teachers who hold constructivist beliefs have strong computer efficacy and show more positive attitudes toward computers in education

The number of online courses was a significant predictor of self-efficacy to complete an online course

Found five sources underlying middle aged and older adults' Internet selfefficacy as, (1) successful performance accomplishments, (2) vicarious admirable modeling by children, friends and neighbors, (3) verbal or social persuasion by influential friends and family, (4) fear, bad memory, slow reactions, or a joyful state and (5) a proactive personality Academic self-efficacy, when operationalized as mastery over domainspecific knowledge, has been found to be a predictor of academic achievement and emotions

Motivation directly influenced the levels of technology self-efficacy, and it was the mediator between the learning strategies and technology self-efficacy

Locus of control, self-efficacy and task value were significant predictors of learner online learning satisfaction Found the importance of individual students' intrinsic goal orientation and academic self-efficacy in academic achievement

Found that the social factors had positive effects on basic Internet self-efficacy and advanced Internet self-efficacy

Computer self-efficacy, meta-cognitive self-regulation and self-concept in online courses were not only positively correlated with student's cognitive and emotional engagement factors but were also negatively correlated with behavioral factors

Table 2. 


\begin{tabular}{lll}
\hline No & Author(s) & Study \\
\hline 27 & Tang et al. (2014) & $\begin{array}{l}\text { Blog learning: effects of users' } \\
\text { usefulness and efficiency toward } \\
\text { continuance intention }\end{array}$
\end{tabular}

28 Komarraju and Dial (2014)

29 Kuo et al. (2014)

30 Taipjutorus (2014)

31 Jan (2015)

32 Wang et al. (2015)

33 Lin et al. (2015)

34 Shen (2015)

35 Lim et al. (2016) Structural relationships of environments, Individuals, and learning outcomes in Korean online university settings

36 Liou et al. (2016) The study of the Antecedents of Knowledge sharing behavior: The empirical study of Yamol online test community courses

The relationship between learner the requirements for the degree of New Zealand efficacy, prior experience, and satisfaction with online learning efficacy perspective

Revalidate forms of presence in of Self-Efficacy

An Empirical Study on Influencing Factors of Knowledge Sharing in Virtual Learning Community

\section{Outcome}

Proposed an extended expectationconfirmation model (ECM) that explicitly incorporates experiential learning, perceived self-efficacy and perceived usefulness to examine blog continuance learning behavioral intentions done online

Found that socially oriented students have lower academic self-efficacy, lower self-determined motivation and a preference for performance goals; reversely studiously oriented students report higher self-esteem and a preference for learning goals

Found learners' self-efficacy and ability of Internet use have positive correlation control and online learning self-efficacy : a thesis presented in partial fulfilment of Doctor of Philosophy in Education at Massey University, Manawatu campus,

Academic self-efficacy, computer self-

Understanding the continuance use of social network sites: a computer selftraining effectiveness: Mediating effect

The study found that computer skills are good predictors of computer self-efficacy

Found academic self-efficacy (ASE) to be most predictive of satisfaction with online learning. Females had a higher mean ASE than males

Found that general computer self-efficacy (CSE) affects continuance intention through both cognition and affection, specific CSE mainly affects continuance intention through cognition

Found social presence was a stronger predictor of self-efficacy. Self-efficacy is a full mediator between social presence and cognitive presence

Found that the trust between members had a significant positive effect on selfefficacy of knowledge-sharing. Effect of perceptual learning on self-efficacy of knowledge-sharing was significant The study showed that learner-learner interaction and system quality was related to learner computer self-efficacy. Content quality also significantly predicted computer self-efficacy Anticipated extrinsic rewards had a significant and positive effect on knowledge sharing self-efficacy. The knowledge sharing self-efficacy partially mediated knowledge sharing behavior 


\section{AAOUJ 15,3}

\begin{tabular}{lll} 
No & Author(s) & Study \\
\hline 37 & Prior et al. (2016) & $\begin{array}{l}\text { Attitude, digital literacy and self- } \\
\text { efficacy: Flow-on effects for online } \\
\text { learning behavior }\end{array}$
\end{tabular}

38 Reychav et al. (2016)

39 Vayre and Vonthron (2016)

40 Cho and Cho (2017)

41 Kim and Park (2017)

$44 \quad$ Hatlevik (2017)

46 Gerick et al. (2017)
Examining the Relationship between Teachers' Self-Efficacy, their Digital Competence, Strategies to Evaluate Information, and use of ICT at School

\section{Self-efficacy toolkit \\ Self-efficacy toolkit}

Leveraging social networks in the adoption of mobile technologies for collaboration

Psychological engagement of students in distance and online learning: Effects of self-efficacy and psychosocial processes

Self-regulation in three types of online interaction: a scale development

Effect of personal factors to use ICTs on e-learning adoption: comparison between learner and instructor in developing countries

in predicting online learning selfefficacy and flow experience relevant to students' learning progress

in predicting online learning selfefficacy and flow experience relevant to students' learning progress

Information, and use of ICT at School

School-level predictors for the use of ICT in schools and students' CIL in international comparison

\section{Outcome}

Found attitude and digital literacy were significantly correlated with self-efficacy. Self-efficacy had a significant positive effect on Peer engagement, Learningmanagement system interactions, and Convener interaction

Found network reciprocity had a strong and significant effect on computer selfefficacy. Perceived enjoyment had a positive effect on computer self-efficacy Found community played a significant and positive role on self-efficacy. Academic self-efficacy partially mediated between the sense of belonging to the learning community and enthusiasm Found self-regulation in interaction between student and content, student and student, and student and teacher, significantly correlated with self-efficacy, respectively

Found personal innovativeness in the domain of ICT identified as an important factor influencing computer self-efficacy for instructors. Computer experience was significantly associated with computer self-efficacy for instructors and for learners

Found that four constructs, namely intrinsic motivation, online learning selfefficacy, flow experience, and learning progress, were all positively correlated The study established mathematically that the relationship between Chinese learning intrinsic motivation and online learning self-efficacy was supported with a path coefficient of $0.382(t=4.35$, $p<0.001)$

Self-efficacy in teaching as a key issue for carrying out good teaching practice and also found a positive relationship between teachers' self-efficacy in information and communication technologies (ICTs)

Found students with high levels of selfefficacy participate more in class, work harder, persist longer, and have fewer adverse emotional reactions when encountering difficulties than students with lower self-efficacy

Use of ICT by teaching staff in schools and their teaching-efficacy differs among different education systems 


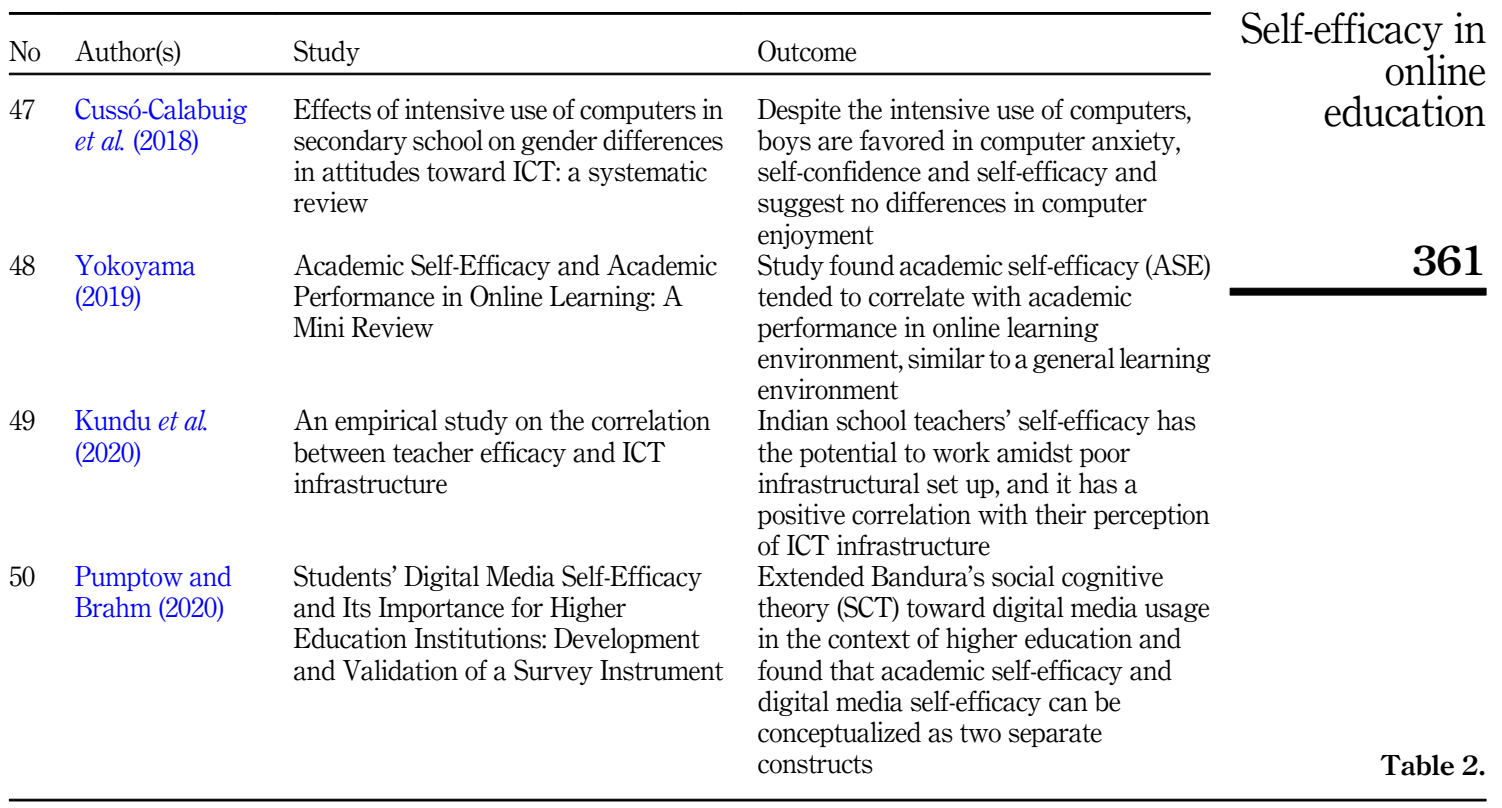

efficacy in online learning, like computer self-efficacy (Pellas, 2014), Internet self-efficacy (Lin et al., 2013; Kuo et al., 2014), digital media self-efficacy (Pumptow and Brahm, 2020), learning management system (LMS), self-efficacy (Prior et al., 2016; Martin et al., 2010) and ICT selfefficacy (Cusso-Calabuig et al., 2018; So et al., 2012). Few studies focused on the role of selfefficacy, task value (Joo et al., 2013) and academic self-efficacy factors (Jan, 2015; Cho and Shen, 2013; Yokoyama, 2019), and few others focused on the general self-efficacy (Gebara, 2010) in online education. Some studies (like Taipjutorus, 2014; Shen et al., 2013) investigated multi-dimension of self-efficacy in online learning. Few contradictory outcomes are also observed when Pellas (2014) and Jan (2015) found that computer self-efficacy and student satisfaction level have no positive or significant relationship conversely, while Kuo et al. (2014) found that learners' self-efficacy and Internet usage have positive correlation. Bates and Khasawneh (2007) found self-efficacy for online technologies to be a good predictor of student performance in online courses and if the students chose to enroll in an online class, it is expected that their technology self-efficacy toward the class was high. Reychav et al. (2016), LaRocca (2017) and Cusso-Calabuig et al. (2018) found that participants' perceived enjoyment in an online course depends on their computer self-efficacy, the root of success in any online course. Taipjutorus (2014) and Hatlevik (2017) demonstrated a positive relationship between self-efficacy and using technology for teaching purposes. Loar (2018) reported that computer self-efficacy in basic and advanced ICT operational and collaborative skills and self-efficacy in using computers for instructional purposes are highly correlated. Few studies found that self-efficacy has a deep impact on the online learning experience and knowledge even the perseverance to complete an online course (i.e. Kim and Park, 2017; Song et al., 2011; Tang et al., 2014; Shen et al., 2013; Prior et al., 2016).

Out of 50 studies, 40 studies were purposively chosen from the Asian context where technology inclusion is very irregular, gender disparity is very popular and skilled teachers are a rarity; here self-efficacy of the participants could be a good instrument amidst impediments, which could provide them an intrinsic motivation to sustain in the teaching- 
AAOUJ 15,3

362 learning activity and continue their fight against the odds (Chiu and Tsai, 2014; Kundu et al., 2020). Hong et al. (2017) mathematically established a positive relationship between Chinese learning intrinsic motivation and online learning self-efficacy. The studies (e.g. Kundu et al., 2020; Lim et al., 2016; Shen, 2015; Kuo et al., 2014; Chiu and Tsai, 2014; Joo et al., 2013; Zhang et al., 2012; Chu, 2010; Song et al., 2011) also found almost in the same tune that self-efficacy has a deep impact on the participants' personal innovativeness, communication climate, holding strong perception toward online infrastructure, motivation, asynchronous communication, learner-learner communication or learner-teachers' communication and knowledge sharing in online mode. Hence, policies to strengthen self-efficacy of the participants could prove effective in the Asian online education context.

\section{$R Q 2$. Factors influencing self-efficacy in online education}

An in-depth analysis found several factors influencing participants' self-efficacy for online education that posit human performance technologists must consider those factors when developing training interventions. Chu (2010) found that emotional family support plays a major role in enhancing Internet self-efficacy, while Chu and Chu (2010) found peer support and e-learning outcomes play as important predictors. Law et al. (2010) found a wellfacilitated e-learning setting can enhance self-efficacy for online learning, while Song et al. (2011) found prior knowledge of online system put a direct effect on online efficacy and participants. Jashapara and Tai (2011) found personal innovativeness with information technology (IT) showed a significant effect on e-learning system self-efficacy, and computer playfulness had a significant positive effect on e-learning system self-efficacy. Zhang et al. (2012) found the psychological safety communication climate as a predictor, Shen et al. (2013) found the number of online courses, Wang et al. (2013) found motivation as a palpable predictor and Chiu and Tsai (2014) found the associated social factors influence self-efficacy for online education. Kuo et al. (2014) suggest that the ability to use the Internet has a positive effect, which is further supported by Taipjutorus (2014). Lin et al. (2008) found social presence as a strong predictor of self-efficacy, while Shen (2015) found the trust between participants as a strong predictor, and Lim et al. (2016) found learner-learner interaction and system quality was related to learners' computer self-efficacy. Among other factors influencing selfefficacy for online education are attitude and digital literacy (Prior et al., 2016), perceived enjoyment (Reychav et al., 2016), community involvement (Vayre and Vonthron, 2016), personal innovativeness (Kim and Park, 2017) and particular education system of the country (Gerick et al., 2017). The studies of Liou et al. (2016) and Wang and Wu (2008) have reported the benefits of feedback and incentive are important factors influencing self-efficacy in online education to find out whether they attain their goals in learning. Online communication was claimed as an important factor influencing self-efficacy in online education, as stated in studies of Lim et al. (2016), Cho and Cho (2017), Lin et al. (2015), Reychav et al. (2016), Shen (2015) and Vayre and Vonthron (2016). Considering the significance of self-efficacy in online education, there is a need to identify and understand these factors influencing participants' self-efficacy. A brief diagram of the factors is furnished for easy understanding in Figure 5.

RQ3. Proposed framework for strengthening participants' self-efficacy

Based on the above analysis, the author proposed a framework for strengthening participants' self-efficacy for online education in the following diagram (see Figure 6) along with few intervention measures presented in Table 3.

Verbal persuasion. The proposed framework presumes that verbal persuasion builds self-efficacy when a respective environment is encouraging and praising individuals with feedbacks for their competence to improve their effectiveness. Empirical evidence behind this proposition is found in a series of studies taken up in this document analysis like Wang and Wu (2008), Chu (2010), Wang et al. (2013), Chiu and Tsai (2014), Tang et al. (2014), Jan (2015), 


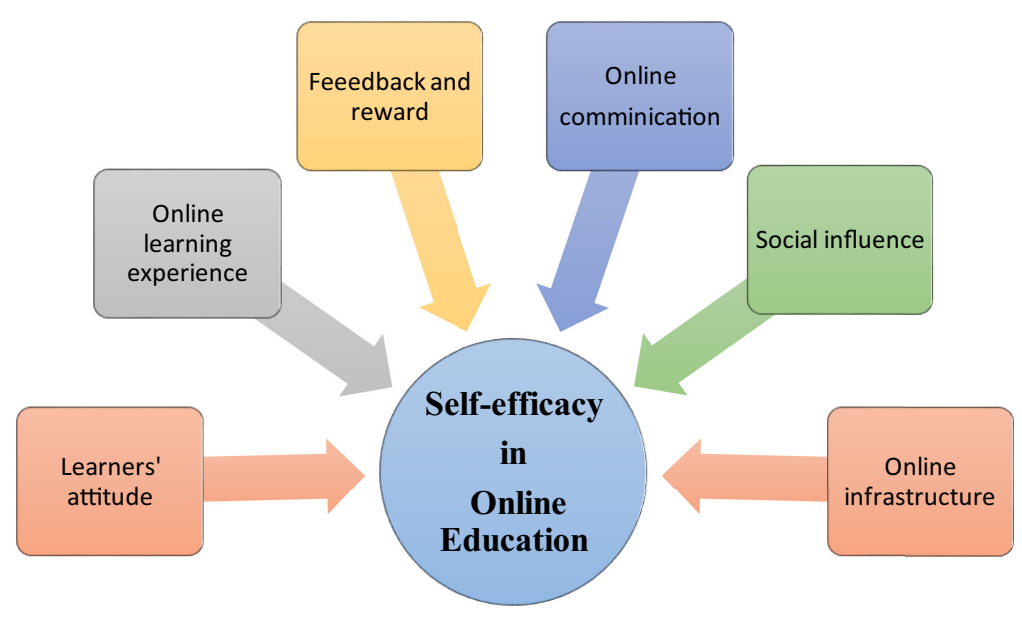

Self-efficacy in online education

363

Lin et al. (2015), Shen (2015), Liou et al. (2016) and Hong et al. (2017), etc. Positive self-talks, informal communications, human relationships, etc. can also raise the self-efficacy level of the participants. The author also concerns with the fact that although encouraging messages have the potential to raise self-efficacy, there are chances that it may collapse into bare sermons unless they are supported by efficacy-affirming experiences (i.e. enactive selfmastery with controlled affective domains). Effective verbal persuasion is needed to be reinforced with corresponding actions. For example, telling individuals that they are capable but not assigning them any practical tasks tends to erode both learners' self-efficacy and the teachers' credibility. The corresponding measures for verbal persuasion domain are presented in Table 3 for both students and teachers. Verbal persuasion may not be possible or practical in several online courses, but a possible equivalent may be convincing a feedback mechanism through email notes, WhatsApp messaging or phone calls to manipulate learners' self-efficacy. The interventions involving written communication were also there in Bandura's verbal persuasion category (Bandura, 2001).

Role modeling. Role modeling reinforced through vicarious experiences or social models. It may be difficult to include vicarious experiences in online education, yet the success stories of peers in the field could be helpful in this context. Empirical evidence is also found in the study of Lin et al. (2015) who said social presence is an important predictor of selfefficacy and in the extended expectation confirmation model propounded by Tang et al. (2014). Observation of models has been investigated and shown to be important for formation of self-efficacy beliefs (Jashapara and Tai, 2011). Hodges (2008) found the solitary often asynchronous environment of online courses does not readily promote opportunities for observing peer observation, yet he empirically proved self-efficacy to learn mathematics asynchronously (SELMA) was positively correlated with the academic achievement of the learners. Here, pedagogical agents for learning (PALs) may be a possible alternative for addressing the vicarious learning component of self-efficacy development in the online educational environment. PALs are explained by Kim and Baylor (2006) as "animated lifelike characters" (Johnson et al., 2000) that are inserted in instructional applications, and it is the ability to simulate social interaction that makes PALs unique form of conventional computer-based environments (p. 570).

Self-mastery. Self-mastery is the development of skills, like thinking, intuiting, communicating, leading, feeling, doing and being, necessary for any academic 


\section{AAOUJ 15,3}

\section{4}

Figure 6.

Framework for enhancing self-efficacy for online education

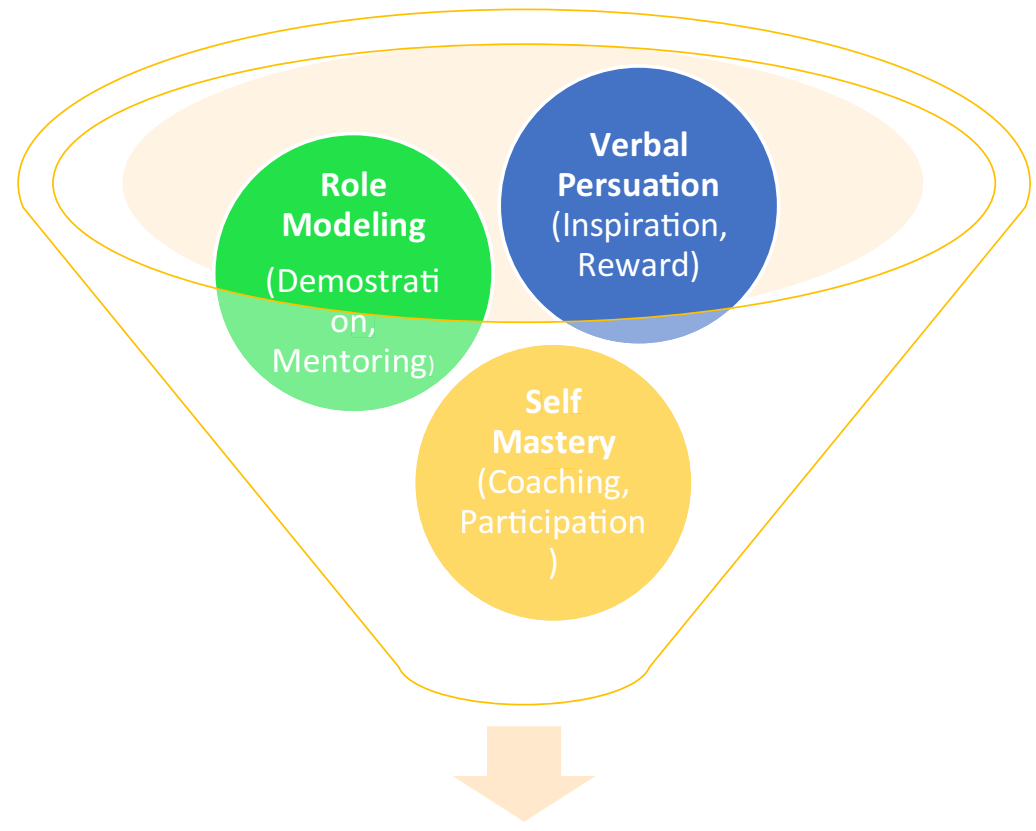

\section{Self-efficacy}

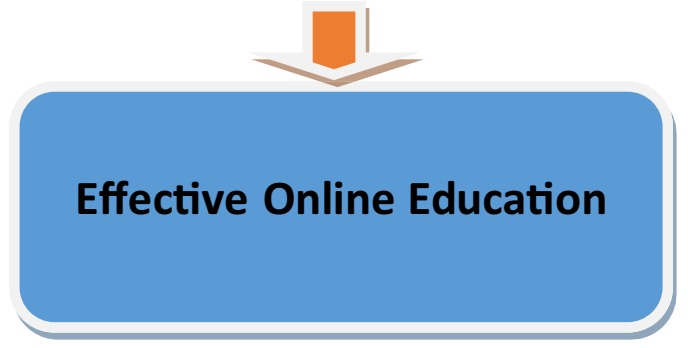

achievement and viewed as the ultimate learning goal (Cunanan and Chua, 2015). Selfmastery is most vital in strengthening participants' self-efficacy in online education, which is reinforced through suitable coaching, practice and participation. Enough of empirical evidence is found in this analysis behind this proposition where learners were found to exhibit more online self-efficacy having more online exposure (Song et al., 2011), with the increase in the number of online course adopted (Shen et al., 2013) and with the increase in computer self-efficacy (Kuo et al., 2014). Kuo et al. (2014) point out that increase in teachers' technology self-efficacy might directly increase their acceptance of technology and also indirectly increase their usage of technology. Furthermore, Shen et al. (2013) asserted that technology self-efficacy has come to play a crucial role in the preparation and implementation of educators who can successfully use educational technology to enhance student learning. This suggestion falls in line with the self-efficacy literature in that beginning with lower-level skills creates opportunities for learners to have early successes before tackling more difficult material. Before self-mastery to take 


\begin{tabular}{ll}
\hline Domains & For teachers \\
\hline $\begin{array}{l}\text { Verbal } \\
\text { persuasion }\end{array}$ & $\begin{array}{l}\text { Encouragement, regular feedbacks, } \\
\text { visions from respective school authorities } \\
\text { and governments to teach online } \\
\text { Teacher-teacher interactions will courage } \\
\text { their ability and efficacy }\end{array}$ \\
(3) & $\begin{array}{l}\text { A clear vision before teachers regarding } \\
\text { what to teach, how to teach and access } \\
\text { will help their smooth function }\end{array}$ \\
(4) stress produced during teaching \\
online, especially from inabilities, needs to \\
be reduced by suitable mentoring and \\
peer support \\
(1) $\begin{array}{l}\text { Success stories of teachers who get } \\
\text { exceptional success in teaching through } \\
\text { online learning should be put before them }\end{array}$ \\
\\
(2) $\begin{array}{l}\text { Several model teaching procedures using } \\
\text { teaching apps like Zoom, Kahoot, Seesaw, } \\
\text { Goolgle classroom, Remind, Classtree, } \\
\text { Dropbox, YouTube, etc may be given to } \\
\text { the teachers to enhance their self-belief } \\
\text { Pedagogical agents for learning (PAL) } \\
\text { may also help in strengthening vicarious } \\
\text { experience Kim and Baylor (2006) }\end{array}$ \\
\end{tabular}

Self- (1) When teachers overcome their obstacles mastery and setbacks with perseverance and resilience they will attain mastery over the online teaching that will strengthen their self-efficacy belief

(2) More practice makes him/her more confident about his/her abilities/skills and reduces his/her chances of failing in the real task

(3) To increase employee self-efficacy, organizations can conduct specialized training programs and orientations that promote self-efficacy

(4) Allowing teachers to express their opinions, active feedback mechanisms, prioritizing targets and helping them with time-management and organizational skills

\section{For students}

(1) Encouragement from parents, teachers and society as a whole will enhance their use of online learning

(2) Constructive feedbacks from teachers and parents will help to strengthen their self-confidence

(3) A clear vision from school authorities and teachers when and how to get benefits from online learning will enhance their belief. The vision and guidelines for how to overcome the infrastructural limitations are also important here

(1) Peer support or peer learning plays a big role. If friends can learn online, why cannot I? The student is expected to put more effort to overcome his/her weaknesses, and it will enhance his efficacy

(2) Animated life-like characters Johnson et al. (2000) embedded in instructional applications or instructional videos and models may serve this purpose

(3) Self-efficacy starts with autonomy and self-regulation. Children who are allowed to decide for themselves and choose their ways are more self-reliant and independent. It is always a good idea to let them choose their tasks, so that they get to do what they want to and not lose interest in it

(1) Students also after overcoming their weaknesses will attain mastery in learning through online that will enhance their sense of efficacy

(2) Students will learn from their past success and failure, for this they need to be offered with a democratic and cooperative learning atmosphere

(3) One students' attainment of selfmastery may encourage others; hence, success stories need circulations

\section{Self-efficacy in online education}

365
Table 3.

Attentions teachers and students need in different domains of self-efficacy

place, earlier two stages - verbal persuasion and role modeling - need to be followed. Thus, to make this framework effective, an institutional ecosystem that develops a desirable culture among all stakeholders and that invests in support services and 
AAOUJ 15,3

infrastructure, such as reliable Internet connections and technology, is necessary. At the same time, institutional vision, leadership and attitudes have a direct bearing on participants including institutional policies on teacher professional development, and the expectation of technology use within teaching and learning, cognizant of potential digital divide issues including student ownership of devices that are incompatible with institutional devices, student's social background, family income and their capability to afford devices need to be considered, as all these have an effect on their efficacy in one way or the other.

\section{Conclusion}

The study reached to this conclusion that self-efficacy is the key to success in online education; hence, a proper understanding is essential. In total, three major sources of selfefficacy - role modeling, verbal persuasion and self-mastery - have been discussed in the context of online education, their roles have been reviewed, especially in the Asian context, and the proposed model is presented along with respective intervention measures. The proposed framework revealed that all stakeholders of online education - students, teachers, institutions, society and parents - have crucial roles for its implementation. The author hopes the framework will prove useful for students, educators and developers operating online, especially for the millions of first-generation and inexperienced participants of online education, who possess low self-confidence in their abilities. However, the proposed model needs to be tested empirically. Hence, this study has a wide scope of future work by conducting empirical studies to test the validity of the model in several socioeconomic contexts.

\section{References}

Ahmed, S.S., Khan, E., Faisal, M. and Khan, S. (2017), "The potential and challenges of MOOCs in Pakistan: a perspective of students and faculty", Asian Association of Open Universities Journal, Vol. 12 No. 1, pp. 94-105, doi: 10.1108/AAOUJ-01-2017-0011.

Alqurashi, E. (2016), "Self-efficacy in online learning environments: a literature review", Contemporary Issues in Education Research, Vol. 9 No. 1, pp. 45-52, doi: 10.19030/cier.v9i1.9549.

Bandalaria, M.D.P. (2018), "Open and distance eLearning in Asia: country initiatives and instructional cooperation for the transformation of higher education in the region", Journal of Learning for Development, Vol. 5 No. 2, pp. 116-132.

Bandura, A. (1997), Self-efficacy: The Exercise of Control, W.H. Freeman and Company, New York.

Bandura, A. (2001), "Social cognitive theory: an agentic perspective", Annual Review of Psychology, Vol. 52, pp. 1-26, doi: 10.1146/annurev.psych.52.1.1.

Bates, R. and Khasawneh, S. (2007), "Self-efficacy and college student' perceptions and use of online learning systems", Computers in Human Behavior, Vol. 23, pp. 175-191, doi: 10.1016/j.chb.2004. 04.004 .

Beaney, M. (2003), “Analysis”, Stanford Encyclopedia of Philosophy, URL (last checked 4 May 2009), available at: http://plato.stanford.edu/entries/analysis/.

Bowen, G.A. (2009), "Document analysis as a qualitative research method", Qualitative Research Journal, Vol. 9 No. 2, pp. 27-40, doi: 10.3316/QRJ0902027.

Chiu, Y.L. and Tsai, C.C. (2014), "The roles of social factor and internet self-efficacy in nurses' webbased continuing learning", Nurse Education Today, Vol. 34, pp. 446-450, doi: 10.1016/j.nedt. 2013.04.013.

Cho, M.H. and Cho, Y.J. (2017), "Self-regulation in three types of online interaction: a scale development", Distance Education, Vol. 38 No. 1, pp. 70-83, doi: 10.1080/01587919.2017.1299563. 
Cho, M.H. and Shen, D. (2013), "Self-regulation in online learning", Distance Education, Vol. 34, pp. 290-301, doi: 10.1080/01587919.2013.835770.

Chowdhury, M. (2020), "4 ways to improve and increase self-efficacy", available at: https:// positivepsychology.com/3-ways-build-self-efficacy/.

Christophersen, K.A., Elstad, E., Turmo, A. and Solhaug, T. (2016), "Teacher education programmes and their contribution to student teacher efficacy in classroom management and pupil engagement", Scandinavian Journal of Educational Research, Vol. 60, pp. 240-254, doi: 10.1080/ 00313831.2015.1024162.

Chu, R.J. (2010), "How family support and Internet self-efficacy influence the effects of elearning among higher aged adults-Analyses of gender and age differences", Computers and Education, Vol. 55, pp. 255-264, doi: 10.1016/j.compedu.2010.01.011.

Chu, R.J. and Chu, A.Z. (2010), "Multi-level analysis of peer support, Internet self-efficacy and e-learning outcomes-The contextual effects of collectivism and group potency", Computers and Education, Vol. 55, pp. 145-154, doi: 10.1016/j.compedu.2009.12.011.

Corry, M. and Stella, J. (2012), "Developing a framework for research in online K-12 distance education”, Quarterly Review of Online Education, Vol. 13 No. 3, pp. 133-151.

Corry, M. and Stella, J. (2018), "Teacher self-efficacy in online education: a review of the literature", Research in Learning Technology, Vol. 26, doi: 10.25304/rlt.v26.2047.

Cunanan, E.J. and Chua, C. (2015), "How teachers view the need to develop self- mastery skills among teacher education students?", Asia Pacific Journal of Multidisciplinary Research, Vol. 3, pp. 105-111.

Cusso-Calabuig, R., Farran, X.C. and Bosch-Capblanch, X. (2018), "Effects of intensive use of computers in secondary school on gender differences in attitudes towards ICT: a systematic review”, Education and Information Technologies, Vol. 23, pp. 2111-2139, doi: 10.1007/s10639018-9706-6.

Deats, R.L. (2005), Mahatma Gandhi, Nonviolent Liberator: A Biography, New City Press, Hyde Park, NY.

Gebara, N.L. (2010), General Self-Efficacy and Course Satisfaction in Online Learning: A Correlational Study, Doctoral dissertation, University of Missouri - Columbia, available at: http://www.editlib. org/p/121111.

Gerick, J., Eickelmann, B. and Bos, W. (2017), "School-level predictors for the use of ICT in schools and students' CIL in international comparison”, Large-scale Assessments in Education, Vol. 5 No. 5, pp. 1-13, doi: 10.1186/s40536-017-0037-7.

Hatlevik, Ove (2017), "Examining the relationship between teachers' self-efficacy, their digital competence, strategies to evaluate information, and use of ICT at school", Scandinavian Journal of Educational Research, Vol. 61, pp. 555-567, doi: 10.1080/00313831.2016.1172501.

Hatlevik, I.K.R. and Hatlevik, O.E. (2018), "Examining the relationship between teachers' ICT selfefficacy for educational purposes, collegial collaboration, lack of facilitation and the use of ICT in teaching practice", Frontiers in Psychology, Vol. 9, p. 935, doi: 10.3389/fpsyg.2018.00935.

Hodges, C. (2008), "Self-efficacy, motivational email, and achievement in an asynchronous math course", Journal of Computers in Mathematics and Science Teaching, Vol. 27 No. 3, pp. 265-285.

Hofstede, G. (1986), "Cultural differences in teaching and learning”, International Journal of Intercultural Relations, Vol. 10, pp. 301-320.

Hong, J.C., Hwang, M.Y., Tai, K.H. and Lin, P.H. (2017), "Intrinsic motivation of Chinese learning in predicting online learning self-efficacy and flow experience relevant to students' learning progress", Computer Assisted Language Learning, Vol. 30 No. 6, pp. 552-574, doi: 10.1080/ 09588221.2017.1329215.

Honicke, T. and Broadbent, J. (2016), "The influence of academic self-efficacy on academic performance: a systematic review", Educational Research Review, Vol. 17, pp. 63-84, doi: 10. 1016/j.edurev.2015.11.002.
Self-efficacy in online education 
AAOUJ 15,3

Jan, S.K. (2015), "The relationships between academic self-efficacy, computer self-efficacy, prior experience, and satisfaction with online learning", American Journal of Distance Education, Vol. 29 No. 1, pp. 30-40, doi: 10.1080/08923647.2015.994366.

Jashapara, A. and Tai, W.C. (2011), "Knowledge mobilization through e-learning system: understanding the mediating roles of Self-Efficacy and Anxiety on perceptions of ease of use", Information Systems Management, Vol. 28 No. 1, pp. 71-83, doi: 10.1080/105805.30.2011. 536115.

Johnson, W.L., Rickel, J.W. and Lester, J.C. (2000), "Animated pedagogical Agents: face-to-face interaction in interactive learning environments", International Journal of Artificial Intelligence in Education, Vol. 11 No. 1, pp. 47-78.

Joo, Y., Lim, K.Y. and Kim, J. (2013), "Locus of control, self-efficacy, and task value as predictors of learning outcome in an online university context", Computers and Education, Vol. 62, pp. 149-158, doi: 10.1016/j.compedu.2012.10.027.

Kim, Y. and Baylor, A.L. (2006), "A social-cognitive framework for pedagogical Agents as learning companions", Retrieved June 14, 2020 from, Educational Technology Research and Development, Vol. 54 No. 6, pp. 569-596, available at: https:/www.learntechlib.org/p/67590/.

Kim, B. and Park, M.J. (2017), Effect of Personal Factors to Use ICTS on E-Learning Adoption: Comparison between Learner and Instructor in Developing Countries, Information Technology for Development, pp. 1-27.

Kitsantas, A. and Chow, A. (2007), "College students' perceived threat and preference for seeking help in traditional, distributed and distance learning environments", Computer and Education, Vol. 48, pp. 383-395, doi: 10.1016/j.compedu.2005.01.008.

Komarraju, M. and Dial, C.M. (2014), "Academic identity, self-efficacy, and self-esteem predict selfdetermined motivation and goals", Learning and Individual Differences, Vol. 32, pp. 1-8, doi: 10. 1016/j.lindif.2014.02.004.Return.to.ref.2014.in.article.

Kundu, A. and Bej, T. (2020), Ingestion and Integration of ICTs for Pedagogy in Indian Private High Schools, E-Learning and Digital Media, SAGE Publications, India. doi: 10.1177/2042753020957493.

Kundu, A., Bej, T. and Dey, K.N. (2020), "An empirical study on the correlation between teacher efficacy and ICT infrastructure", International Journal of Information and Learning Technology, Vol. 37 No. 4, pp. 213-238, doi 10.1108/IJILT-04-2020-0050.

Kuo, Y.C., Walker, A.E., Schroder, K.E.E. and Belland, B.R. (2014), "Interaction, Internet self-efficacy, and self-regulated learning as predictors of student satisfaction in online education courses", The Internet and Higher Education, Vol. 20, pp. 35-50, doi: 10.1016/j.iheduc.2013.10.001.

LaRocca, B. (2017), "Self-efficacy toolkit. Transforming education", available at: https://www. transformingeducation.org/self-efficacy-toolkit/.

Law, K.M.Y., Lee, V.C.S. and Yu, Y.T. (2010), "Learning motivation in e-learning facilitated computer programming courses", Computers and Education, Vol. 55, pp. 218-228, doi: 10.1016/j.compedu. 2010.01.007.

Lee, J.K. and Hwang, C.Y. (2007), "The effects of computer self-efficacy and learning management system quality on e-Learner's satisfaction", available at: https://www.lamsfoundation.org/ lams2007/pdfs/Lee_Hwang_LAMS2007.pdf.

Lim, K., Kang, M. and Park, S.Y. (2016), "Structural relationships of environments, Individuals, and learning outcomes in Korean online university settings", International Review of Research in Open and Distance Learning, Vol. 17 No. 4, pp. 315-330, doi: 10.19173/irrodl.v17i4.2500.

Lin, Y.M., Lin, G.Y. and Laffey, J.M. (2008), "Building a social and motivational framework for understanding satisfaction in online learning", Journal of Educational Computing Research, Vol. 38 No. 1, pp. 1-27, doi: 10.2190/EC.38.1.a.

Lin, Y.C., Liang, J.C., Yang, C.J. and Tsai, C.C. (2013), "Exploring middle-aged and older adults' sources of internet self-efficacy: a case study", Computers in Human Behavior, Vol. 29 No. 6, pp. 2733-2743, doi: 10.1016/j.chb.2013.07.017. 
Liou, D.K., Chih, W.H., Yuan, C.Y. and Lin, C.Y. (2016), "The study of the antecedents of knowledge sharing behavior: the empirical study of Yamol online test community", Internet Research, Vol. 26 No. 4, pp. 845-868.

Liu, X., Liu, S., Lee, S.H. and Magjuka, R.J. (2010), "Cultural differences in online learning: international student perceptions”, Educational Technology and Society, Vol. 13 No. 3, pp. 177-188.

Loar, E.A. (2018), “Computer self-efficacy revisited”, Journal of Instructional Research, Vol. 7, pp. 55-59, doi: $10.9743 /$ jir.2018.4.

Lynch, R. and Dembo, M. (2004), "The relationship between self-regulation and online learning in a

Self-efficacy in online education blended learning context", International Review of Research in Open and Distance Learning, Vol. 5 No. 2, doi: 10.19173/irrodl.v5i2.189.

Martin, F., Tutty, J.I. and Su, Y. (2010), "Influence of learning management systems self-efficacy on E-learning performance”, I-manager's Journal on School Educational Technology, Vol. 5 No. 3, pp. 26-35, available at: http://www.imanagerpublications.com/Archives.aspx.

O'Leary, Z. (2014), The Essential Guide to Doing Your Research Project, 2nd ed., Sage Publications, Thousand Oaks, CA.

Paul, G. (2020), "The role of theory and randomized trials for education policy in developing countries", World Development, Vol. 127, doi: 10.1016/j.worlddev.2019.104801.

Pellas, N. (2014), "The influence of computer self-efficacy, metacognitive self-regulation and selfesteem on student engagement in online learning programs: evidence from the virtual world of second life", Computers in Human Behavior, Vol. 35, pp. 157-170, doi: 10.1016/j.chb.2014.02.048.

Peterson, T.O. and Arnn, R.B. (2005), "Self-efficacy: the foundation of human performance", Performance Improvement Quarterly, Vol. 18, pp. 5-18, doi: 10.1111/j.1937-8327.2005.tb00330.x.

Prior, D.D., Mazanov, J., Meacheam, D., Heaslip, H. and Hanson, J. (2016), “Attitude, digital literacy and self-efficacy: flow-on effects for online learning behavior", The Internet and Higher Education, Vol. 29, pp. 91-97, doi: 10.1016/j.iheduc.2016.01.001.

Pumptow, M. and Brahm, T. (2020), "Students' digital media self-efficacy and its importance for higher education institutions: development and validation of a survey instrument", Tech Know Learn. doi: 10.1007/s10758-020-09463-5.

Putwain, D., Sander, P. and Larkin, D. (2013), "Academic self-efficacy in study-related skills and behaviours: relations with learning-related emotions and academic success", The British Journal of Educational Psychology, Vol. 83 No. 4, pp. 633-650, doi: 10.1111/j.2044-8279.2012.02084.x.

Reychav, I., Ndicu, M. and Wu, D. (2016), "Leveraging social networks in the adoption of mobile technologies for collaboration”, Computers in Human Behavior, Vol. 58, pp. 443-453, doi: 10. 1016/j.chb.2016.01.011.

Shea, P. and Bidjerano, T. (2010), "Learning presence: towards a theory of self-efficacy, self-regulation, and the development of a communities of inquiry in online and blended learning environments", Computers and Education, Vol. 55 No. 4, pp. 1721-1731, doi: 10.1016/j.compedu.2010.07.017.

Shen, B. (2015), "An empirical study on influencing factors of knowledge sharing in virtual learning community", The Open Cybernetics and Systemics Journal, Vol. 9, pp. 2332-2338, doi: 10.2174/ 1874110 X01509012332.

Shen, D., Cho, M.H., Tsai, C.L. and Marra, R. (2013), "Unpacking online learning experiences: online learning self-efficacy and learning satisfaction", The Internet and Higher Education, Vol. 19, pp. 10-17, doi: 10.1016/j.iheduc.2013.04.001.

So, H.J., Choi, H., Lim, W.Y. and Xiong, Y. (2012), "Little experience with ICT: are they really the net generation student-teachers?”, Computers and Education, Vol. 59, pp. 1234-1245, doi: 10.1016/j. compedu.2012.05.008.

Song, H.S., Kalet, A.L. and Plass, J.L. (2011), "Interplay of prior knowledge, self-regulation and motivation in complex multimedia learning environments", Journal of Computer Assisted Learning, Vol. 32, pp. 31-50, doi: 10.1111/jcal.12117. 
AAOUJ 15,3

Sun, A. and Chen, X. (2016), "Online education and its effective practice: a research review", Journal of Information Technology Education: Research, Vol. 15, pp. 157-190, doi: 10.28945/3502.

Taipjutorus, W. (2014), The Relationship between Learner Control and Online Learning Self-Efficacy: A Thesis Presented in Partial Fulfilment of the Requirements for the Degree of Doctor of Philosophy in Education at, Massey University, Manawatu campus, New Zealand.

Talsma, K., Schüza, B., Schwarzerc, R. and Norrisa, K. (2018), "I believe, therefore I achieve (and vice versa): a meta-analytic cross-lagged panel analysis of self-efficacy and academic performance", Learning Individual Differences, Vol. 61, pp. 136-150, doi: 10.1016/j.lindif.2017.11.015.

Tang, J.T.E., Tang, T.I. and Chiang, C.H. (2014), "Blog learning: effects of users' usefulness and efficiency towards continuance intention”, Behavior and Information Technology, Vol. 33 No. 1, pp. 36-50, doi: 10.1080/0144929X.2012.687772.

The World Bank (2019), Quick Guide: ICT and Education at the Asian Development Bank, available at: https://www.worldbank.org/en/search?q=asian+development.

Tschannen-Moran, M., Hoy, A.W. and Hoy, W.K. (1998), "Teacher efficacy: its meaning and measure”, Review of Educational Research, Vol. 68 No. 2, pp. 202-248, doi: 10.3102/00346543068002202.

Tsai, C.-C. (2017), "Conceptions of learning in technology-enhanced learning environments: a review of case studies in Taiwan", Asian Association of Open Universities Journal, Vol. 12 No. 2, pp. 184-205, doi: 10.1108/AAOUJ-12-2017-0038.

Vayre, E. and Vonthron, A.M. (2016), "Psychological engagement of students in distance and online learning: effects of self-efficacy and psychosocial processes", Journal of Educational Computing Research, Vol. 55 No. 2, pp. 197-218, doi: 10.1177/0735633116656849.

Wang, S.L. and Wu, P.Y. (2008), "The role of feedback and self-efficacy on web-based learning: the social cognitive perspective", Computers and Education, Vol. 51, pp. 1589-1598, doi: 10.1016/j. compedu.2008.03.004.

Wang, C.H., Shannon, D.M. and Ross, M.E. (2013), "Student' characteristics, selfregulated learning, technology self-efficacy, and course outcomes in online learning", Distance Education, Vol. 34 No. 3, pp. 302-323, doi: 10.1080/01587919.2013.835779.

Wang, D., Xu, L. and Hock, C.C. (2015), "Understanding the continuance use of social network sites: a computer self-efficacy perspective", Behaviour and Information Technology, Vol. 34 No. 2, pp. 204-216, doi: 10.1080/0144929X.2014.952778.

Woolfolk, A. (2011), Educational Psychology: Active Learning, 11th ed., Pearson Education, Boston, MA.

Yokoyama, S.(2019), "Academic self-efficacy and academic performance in online learning: a mini review", Frontiers in Psychology, Vol. 9, p. 2794, doi: 10.3389/fpsyg.2018.02794.

Yukselturk, E. and Bulut, S. (2007), "Predictors for student success in an online course", Educational Technology and Society, Vol. 10, pp. 71-83.

Zhang, Y., Fang, Y., Wei, K.K. and Wang, Z. (2012), "Promoting the intention of students to continue their participation in e-learning systems", Information Technology and People, Vol. 25 No. 4, pp. 356-375, doi: 10.1108/09593841211278776.

\section{Corresponding author}

Arnab Kundu can be contacted at: arnabkundu5@gmail.com

For instructions on how to order reprints of this article, please visit our website:

www.emeraldgrouppublishing.com/licensing/reprints.htm

Or contact us for further details: permissions@emeraldinsight.com 